and is frequently invited to serve in bilateral activities between Canada and the U.S. He has travelled to study forestry in many countries on five continents. He was also the recipient of the
Canadian Institute of Forestry International Forestry Award in 1990.

CIF/IFC News Release

\title{
Discussion Paper on Suggested Interrelationships and Various Functions of the CIF/IFC
}

The Canadian Institute of Forestry/ Institut Forestier du Canada is the only national forestry association that represents professionals practising forestry across Canada and congregates some 2,500 members from one end of the country to the other.

The objectives of the CIF/IFC are clearly stated:

1. To improve all aspects of forestry in Canada.

2. To foster public understanding of forestry, forests and forest industry including their importance to the economy and their role in the maintenance and improvement of environmental quality.

3. To advance members in their knowledge of forestry.

4. To cultivate an esprit de corps among members.

5. To publish a professional and scientific forestry journal.

6 . To cooperate with other organizations having similar objectives.

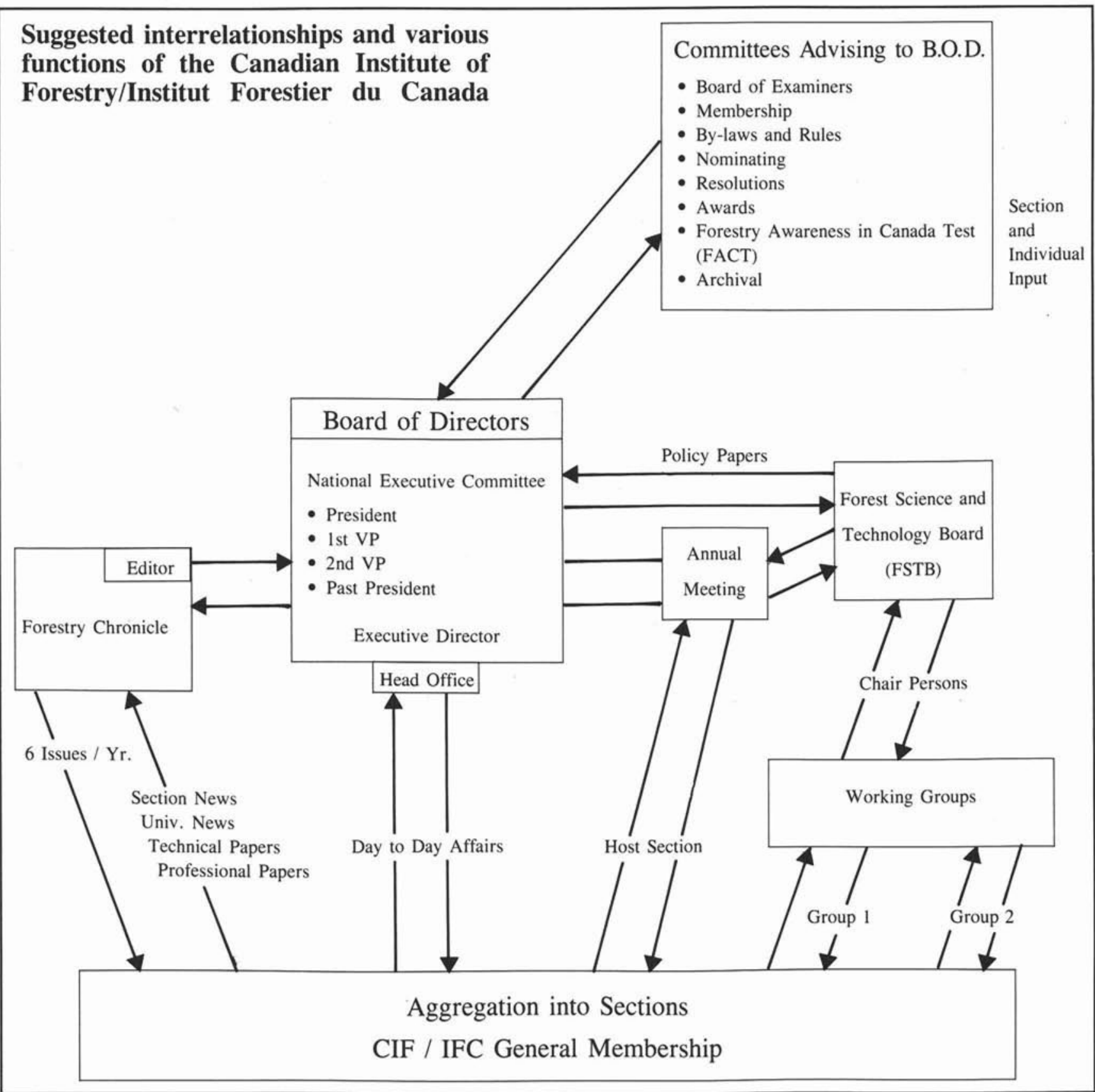


To achieve these objectives, a number of different responsibility groups have evolved and will continue to increase in numbers as the CIF/IFC expands and grows. For example there exists:

- some 22 sections

- Executive Director

- Head Office Staff

- National Executive Committee

- Board of Directors

- Editors, Forestry Chronicle

- Forestry Chronicle

- Annual Meeting

- Working Groups, some 13

- Forest Science and Technology Board

- Various committees advising the Board of Directors

Each of the above has separate objectives or purposes within the overall $\mathrm{CIF} / \mathrm{IFC}$ mandate while each has necessary interrelationships with the other groups which assist in fulfilling their mandates.

Compounding this multi-responsibility function and interrelationship is the fact that most of the positions within the organization are held by volunteers who rotate on a periodical basis and in different capacities. It is believed that an opportunity exists to assist all these various responsibility groups, staffed primarily by volunteers, to improve the understanding of the interrelationships within the CIF/IFC without creating additional bureaucracy. This improved understanding will also assist in motivating our large body of volunteers.

One suggestion is that a responsibility or organization chart be developed that delineates the interaction between the various groups of the CIF/IFC. An example is shown.

A second suggestion is to develop a responsibility function or reporting relationship for each group. Who ultimately do all the groups report to? The Board of Directors, the general membership or the sections? Is the Board of Directors presently representing all the groups of the national organization or just the sections?

A third suggestion is to have each group define their own objective functions and how they assist in achieving the overall CIF/IFC objectives.

And finally, a fourth suggestion is to have each group develop a strategic plan that is practical and will assist the groups in achieving their objectives as well as those of the CIF/IFC.
In summary, it is believed that some simple documentation of our existing organization will develop a purpose that our many changing volunteers can enthusiastically respond to. People, given some purpose and minimal direction, will effectively respond. It is suggested that the four above ideas, if applied, would assist in communicating the objectives, responsibility functions, interrelationships, along with individual and total CIF/IFC strategic plans. Minimal effort would be required to facilitate or co-ordinate the development of such a plan. What do you think?

Bob Craig, Chairperson Vancouver Section

\section{Section News/Nouvelles des sections}

\section{Orleans}

Lors de la première d'une série de conférences traitant de grands sujets d'actualités forestières au Québec, l'Exécutif de la section Orléans invitait monsieur André Delisle, Président de la Commission sur la protection des forêts à présenter les grandes lignes du rapport «Des forêts en santé» rendu public deux semaines plus tôt. Messieurs Richard Lacasse de l'Association des manufacturiers de bois de sciage du Québec (AMBSQ), Jean-Pierre Drapeau de l'Union québécoise pour la conservation de la nature (UQCN) et Luc Palmer, directeur de la foresterie et de l'environnement à la compagnie Domtar, étaient également invités à présenter leur point de vue sur ce rapport d'enquête et d'audiences publiques. M. Claude Godbout, doyen de la Faculté de foresterie et de géomatique de l'Université Laval, agissait à titre de modérateur. Quelque 85 personnes ont participé à l'évènement.

Rappelons que ce rapport découle du "projet de Stratégie de protection des forêts" rendu public en janvier 1991, et soumis volontairement à la consultation publique par le ministre des Forêts du Québec, M. Albert Côté.

Dans son exposé, M. Delisle a mis l'accent sur les faits soulevés tout au long des audiences. Il a d'abord mentionné que le public a généralement perçu le projet du MFO comme un document novateur. La commission a d'ailleurs repris intégralement 10 des 29 recommendations du MFO. Le public a aussi fait part de certaines préoccupations qui étaient, selon la commission, peu ou pas traitées dans le projet du MFO. C'est ainsi que 19 recommandations ont été reformulées et qu'une quarantaine d'autres ont été ajoutées. Ces dernières visent principalement à harmoniser la récolte du bois avec les autres formes d'utilisation de la forêt et à associer davantage les citoyens dans l'aménagement de la forêt. M. Delisle a mentionné que les communautés misent sur une responsabilisation accrue des

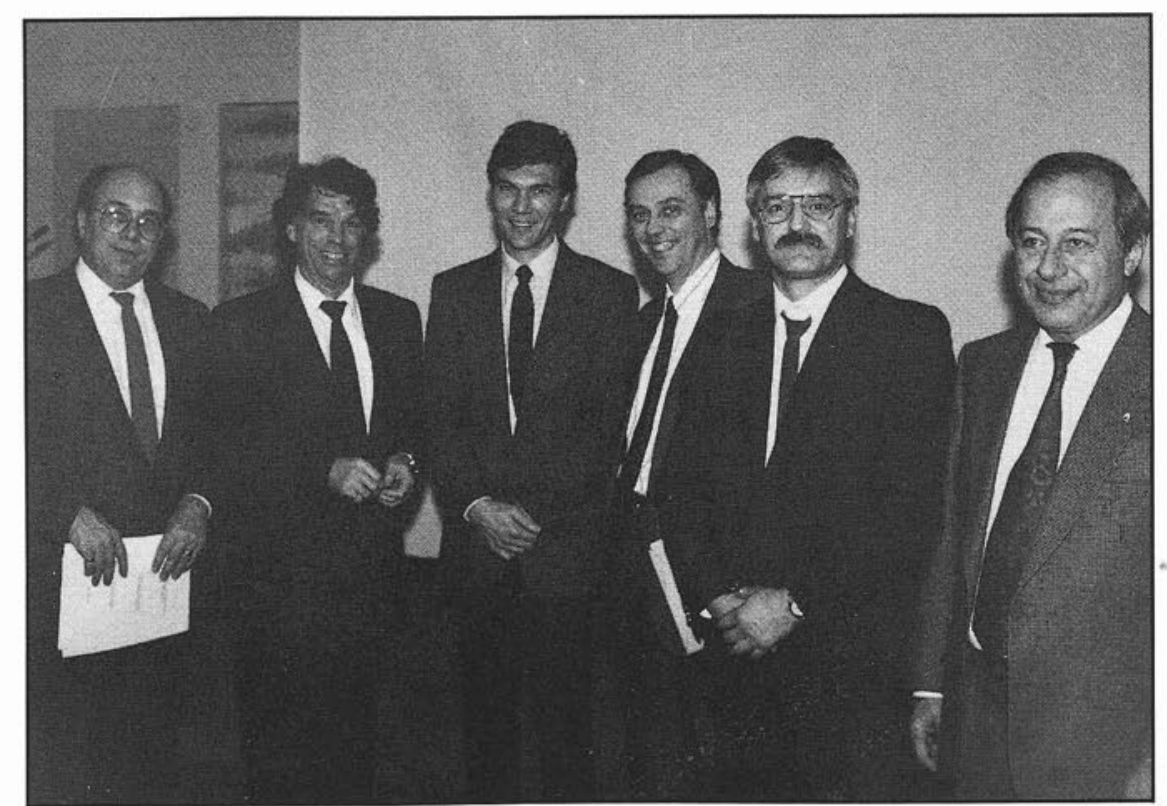

Nous voyons, de gauche à droite, Messieurs Claude Godbout, André Delisle, Pierre Y. Bernier, président de la section Orléans, Luc Palmer, Jean-Pierre Drapeau, et Richard Lacasse. 